\title{
ANALISIS KEMAMPUAN RASIO LIKUIDITAS DAN PROFITABILITAS DALAM MENGUKUR FINANCIAL DISTRESS
}

\section{ANALYSIS OF LIQUIDITY AND PROFITABILITY RATIO CAPABILITIES IN MEASURING FINANCIAL DISTRESS}

\author{
Muhammad Iksan Sopian ${ }^{1}$, Erry Sunarya ${ }^{2}$, Kokom Komariah ${ }^{3}$ \\ Fakultas Ilmu Administrasi dan Humaniora, Universitas Muhammadiyah Sukabumi ${ }^{1,2,3}$ \\ ishanbacang@gmail.com ${ }^{1}$
}

\begin{abstract}
Financial distress is a condition where the results of the company's performance are unable to meet the company's obligations. The purpose of this research is to find out the effect of Liquidity and Profitability in measuring financial distress in PT .eterindo wahanatama Tbk and PT. Waskita Karya Tbk. The analysis technique used is multiple linear analysis techniques, and for hypothesis testing is a partial statistical test ( $t$ test) and simultaneous test ( $f$ test). The results of the t test show that liquidity (CR) (X1) has an effect but not significant to financial distress, Profitability (ROA) (X2) has a significant effect on financial distress. Based on the simultaneous $F$ test means that together Liquidity (CR) and Profitability (ROA) have no significant effect on purchasing decisions (Y). Based on the test of the coefficient of determination of 0.354 it can be interpreted that the effect of Liquidity (CR) and Profitability (ROA) on purchasing decisions is equal to $28.4 \%$. The remaining $71.6 \%$ is influenced by other factors not explained in this study.
\end{abstract}

Keywords : Liquidity, Profitability, financial Distress.

\begin{abstract}
ABSTRAK
Financial distress adalah kondisi dimana hasil dari kinerja perusahaan tidak mampu mencukupi kewajiban perusahaan. Tujuan dari penelitian ini adalah untuk mengetahui pengaruh Likuiditas dan Profitabilitas dalam mengukur financial distress di PT .eterindo wahanatama Tbk dan PT. Waskita Karya Tbk. Teknik analisis yang digunakan adalah teknik analisis linear berganda, dan untuk pengujian hipotesis adalah uji statistik parsial (uji t) dan uji simultan (uji f). Hasil uji t menunjukkan bahwa likuiditas (CR) (X1) berpengaruh tetapi tidak signifikan terhadap financial distress, Profitabilitas (ROA) (X2) memiliki pengaruh signifikan terhadap financial distress. Berdasarkan uji $\mathrm{F}$ simultan berarti bahwa secara bersama Likuiditas (CR) dan Profitabilitas (ROA) tidak memiliki pengaruh yang signifikan terhadap keputusan pembelian (Y). Berdasarkan uji koefisien determinasi sebesar 0,354 maka dapat diartikan bahwa pengaruh Likuiditas (CR) dan Profitabilitas (ROA) terhadap keputusan pembelian adalah sebesar 28,4\%. Sisanya $71,6 \%$ dipengaruhi oleh faktor lain yang tidak dijelaskan dalam penelitian ini.
\end{abstract}

Kata Kunci: Likuiditas, Profitabilitas, Kesulitan keuangan. 


\section{PENDAHULUAN}

Permasalahan dalam keuangan yaitu salah satu masalah yang sangat berbahaya untuk suatu perusahaan dalam perkembangan bisnis disemua perusahaan. Karena salah satu didirikanya suatu perusahaan yaitu untuk memperoleh laba yang maksimal. Namun berhasil atau tidaknya suatu perusahaan dalam mencari laba dan mempertahankan perusahaanya itu tergantung dari laporan keuangan.

Saat ini semakin kerasnya persaingan didalam berbisnis masingmasing perusahaan berusaha mengokohkan pondasi bisnis mereka dengan semaksimal mungkin, dan berbagai macam cara tentu dengan managemen yang baik dan benar, sumber daya yang bagus pula yang mereka pakai untuk pengembangan serta penguatan perusahaan dari berbagai sektor, salah satunya sektor keuangan atau managemen keuangan, hal ini sangat lah penting untuk mempertahankan suatu perusahaan laporan keuangan ini harus sangat teliti dan di jalankan oleh pakar keuangan , karena hal ini yang akan pertama dilihat oleh pihak investor agar mereka tertarik berinvestasi pada perusahaan tersebut.

Financial distress suatu perusahaan dapat dilihat dan diukur melalui laporan keuangan. Financial distress adalah kondisi dimana hasil dari kinerja perusahaan tidak mampu mencukupi kewajiban perusahaan, ini disebabkan beberapa faktor yang menjadikan kondisi perusahaan seperti ini, bisa dilihat dari kinerja perusahaan yang tidak maksimal dalam pengoprasian yang dilakukan perusahaan. Financial distress ini terjadi karena kurang maksimalnya kinerja dari perusahaan sehingga mengakibatkan terjadinya penurunan laba perusahaan yang cukup signifikan apalagi ini terjadi beberapa tahun bahkan berturut-turut, artinya ada suatu permasalahan yang akan timbul dari penyebab masalah tersebut salah satunya kegagalan perusahaan untuk bisa membayar kewajiban jangka panjang dan pendeknya yaitu financial distress.

Laporan keuangan adalah salah satu kunci dimana perusahaan bisa terlihat dari setiap tahunnya dari keuangan yang diterbitkan oleh perusahaan merupakan salah satu sumber informasi yang sangat penting untuk mengenai posisi keuangan perusahaan, kinerja serta perubahan posisi keuangan perusahaan. Perusahaan perlu melakukan analisis laporan keuangan untuk memprediksi financial distress karena laporan keuangan digunakan untuk menilai kinerja perusahaan, dan digunakan untuk membandingkan kondisi perusahaan dari tahun sebelumya dengan tahun sekarang perusahaan tersebut meningkat atau tidak, sehingga perusahaan mempertimbangkan keputusan yang akan diambil untuk tahun yang akan datang sesuai dengan kinerja perusahaanya.

Rasio dapat dihitung berdasarkan sumber data yang terdiri dari rasio-rasio yaitu neraca, Neraca yaitu rasio yang disusun dari data yang berasal dari laporan keuangan, rasio-rasio laporan laba rugi yang disusun berdasarkan dari perhitungan laba rugi, Laporan keuangan perlu disusun guna mengetahui apakah kemampuan perusahaan tersebut meningkat atau bahkan merugi dan didalam menganalisis financial distress diperlukan alat analisis keuangan salah satunya adalah dengan menggunakan rasio.

$$
\text { Rasio disebut sebagai }
$$
perbandingan jumlah, dari satu jumlah 
dengan jumlah yang lainnya, dilihat perbandingan dengan harapan nantinya akan ditemukan jawaban yang selanjutnya itu dijadikan bahan kajian untuk dianalisis dan diputuskan, beberapa rasio yang dipergunakan di dalam analisis ini adalah Rasio Likuiditas dan Profitabilitas.

Rasio Profitabilitas untuk menunjukan keberhasilan perusahaan didalam menghasilkan keuntungan dan Rasio Likuiditas merupakan rasio yang menunjukan bagaimana perusahaan mampu untuk memenuhi kewajiban lancar secara tepat waktu, dalam rangka memperoleh keuntungan dan juga kemampuan untuk melunasi hutangnya kembali.

Rasio Likuiditas merupakan rasio yang menggambarkan kemampuan perusahaan dalam memenuhi kewajiban jangka pendek. Fungsi lain rasio likuiditas adalah untuk menunjukan atau mengukur kemampuan perusahaan dalam memenuhi kewajibannya yang jatuh tempo, baik kewajibannya kepada pihak luar perusahaan (likuiditas badan usaha) maupun didalam perusahaan (likuiditas perusahaan). Atau dengan kata lain, rasio likuiditas merupakan yang menunjukan kemampuan perusahaan untuk membayar utangutang (kewajiban) jangka pendeknya yang jatuh tempo, atau rasio untuk mengetahui kemampuan perusahaan dalam membiayai dan memenuhi kewajiban (utang) pada saat ditagih.

Menurut Fahmi (2017) Rasio Likuiditas (liquidity ratio) adalah kemampuan suatu perusahaan memenuhi kewajiban jangka pendeknya secara tepat waktu. Contoh membayar listrik, telefon, air PDAM, gaji karyawan, gaji teknisi, gaji lembur, tagihan telefon, dan sebagainya. Karena itu rasio likuiditas sering disebut dengan short term liquidity. $\begin{array}{llr}\text { Menurut } & \begin{array}{c}\text { Munawir, (2007) } \\ \text { sebagai } \\ \text { dikemukakan } \\ \text { "Likuiditas } \\ \text { adalah }\end{array}\end{array}$ kemampuan suatu perusahaan untuk memenuhi kewajiban keuanganya yang harus dipenuhi, atau kemampuan perusahaan untuk memenuhi kewajiban keuangan pada saat ditagih. Perusahaan yang mampu memenuhi kewajiban keuangan tepat pada waktunya berarti perusahaan tersebut dalam keadaan "likuid", dan perusahaan dikatakan mampu memenuhi kewajiban keuangan tepat pda waktunya apabila perusahaan tersebut memiliki alat pembayaran ataupun aktiva lancar yang lebih besar daripada hutang lancarnya atau hutang jangka pendek. Sebaliknya kalau perusahaan tidak dapat segera memenuhi kewajiban keuanganya pada saat ditagih, berarti perusahaan tersebut dalam keadaan "likuid".

Adapun rumus likuiditas yang digunakan pada penelitian ini yaitu menggunakan Current Ratio (CR) menurut Subrayaman dann Wild dalam Puspitawati (2017) adalah :

$$
\text { Current Ratio }=\frac{\text { Aset Lancar }}{\text { Utang Lancar }}
$$

Menurut Kasmir (2015) rasio profitabilitas (profitability ratio) Rasio profitabilitas merupakan rasio untuk menilai kemampuan perusahaan dalam mencari keuntungan atau laba dalam suatu periode tertentu. Rasio ini juga memberikan ukuran untuk efektivitas manajemen suatu perusahaan yang ditunjukan dari laba yang dihasilkan dair penjualan atau dari pendapatan investasi. Dikatakan perusahaan rentabilitasnya baik apanila mampu memenuhi target laba yang telah ditetapkan dengan menggunakan aktiva atau modal yang dimilikinya". Rasio profitabilitas atau rasio rentabilitas dibagi 2 yaitu sebagai berikut: 1) 
Rentabilitas ekonomi, yaitu dengan membandingkan laba usaha dengan seluruh modal ( modal sendiri dan asing), 2) Rebtabilitas usaha (sendiri) yaitu dengan membandingkan laba yang disediakan untuk pemilik dengan modal sendiri.Rentabilitas tinggi lebih penting dari keuntungan yang besar.

Menurut Munawir, (2007) dikemukakan sebagai berikut: Rasio Rentabilitas atau Profitability, "adalah menunjukan kemampuan perusahaan untuk menghasilkan laba selama periode tertentu. Rentabilitas suatu perusahaan dapat diukur dengan kesuksesan perusahaan dan kemampuan menggunakan aktivanya secara produktiv, dengan demikian rentabilitas suatu perusahaan dapat diketahui dengan memperbandingkan antara laba yang diperoleh dalam satu periode dengan jumlah aktiva atau modal perusahaan".

Didalam Rasio profitabilitas ini penulis menggunakan Return On Asset (ROA) adapun rumus dari ROA adalah sebagai berikut :

$$
\text { ROA }=\frac{\text { Laba Bersih }}{\text { Total Aset }}
$$

Menurut Hanafi (2007) financial distress adalah : financial distress dapat digambarkan dari dua titik estrem yaitu kesulitan likuiditas jangka pendek sampai insolvabel. Kesulitan keuangan jangka pendek biasanya bersifat jangka pendek, tetapi bisa berkembang menjadi parah. Indikator kesulitan keuangan dapat dilihat dari aliran kas, analisis strategi perusahaan dan laporan keuangan perusahaan.

Menurut Darsono \& Ashari (2005), financial distress dapat diartikan sebagai ketidak mampuan perusahaan untuk membayar kewajiban keuangan pada saat jatuh tempo yang menyebabkan kebangkrutan perusahaan
Financial distress merupakan suatu masalah keuangan yang dihadapi oleh sebuah perusahaan yang ditandai dengan adanya ketidakpastian laba bersih pada masa yang akan datang dan kondisi financial distress terjadi sebelum perusahaan benar-benar mengalami kebangkrutan.

Untuk melihat suatu perusahaan mengalami financial distress atau tidak maka salah satu alat untuk menentukan financial distress yaitu dengan melihat laporan keuangan. Laporan keuangan merupakan alat untuk mengambarkan kondisi keuangan perusahaan, dan prestasi yang telah dicapai oleh perusahaan dari hasil usahanya yang dapat dimanfaatkan sebagai sumber informasi bagi berbagai pihak yang memiliki kepentingan dengan laporan keuangan tersebut. Dimana pihak tersebut akan mengambil keputusan berdasarkan kondisi yang digambarkan pada laporan keuangan.

Fahmi (2014) menyatakan bahwa interest Coverage Ratio dapat mengukur tingkat kesulitan keuangan yang dialami oleh perusahaan. Rumus interest Coverage Ratio adalah sebagai berikut :

$$
\begin{aligned}
& \text { Interest Coverage Ratio } \\
& =\frac{\text { Earning After Tax }(E B T)}{\text { Interest Expense }}
\end{aligned}
$$

Untuk menggambarkan kemampuan perusahaan dalam memperoleh keuntungan menggunakan semua sumber yang ada seperti kegiatan dalam penjualan, kas modal, jumlah karyawan, jumlah cabang dan sebagainya dapat diukur menggunakan rasio profitabilitas. Perusahaan yang mempunyai nilai profitabilitas yang tinggi berarti perusahaan memiliki laba yang besar, ini berarti perusahaan tersebut semakin kecil kemungkinan mengalami financial distress. Menurut 
Lily Puspitasari (2017) dalam penelitiannya menyatakan bahwa profitabilitas (ROA) mempunyai pengaruh signifikan dalam memprediksi financial distress.

Menurut Irham Fahmi (2014) menyatakan bahwa, jika suatu perusahaan mengalami masalah dalam likuiditas maka sangat memungkinkan perusahaan tersebut mulai memasuki masa kesulitan keuangan (financial distress) dann jika kondisi kesulitan tersebut tidak cepat diatasi maka bisa mengakibatkan kebangkrutan usaha (bankcruptcy). Puspitasari (2017) dalam penelitiannya menyatakan bahwa rasio likuiditas yang di proyeksikan menggunakan current ratio berpengaruh signifikan terhadap kemungkinan terjadinya financial distress disuatu perusahaan.

\section{METODE PENELITIAN}

Metode penelitian yang digunakan peneliti untuk menemukan dan mendapatkan jawaban untuk masalah yang diteliti adalah dengan metode deskriptif dan asosiatif. Deskriptif dilakukan untuk mengatahui nilai variabel mandiri Dalam penelitian ini deskriptif digunakan untuk mengetahui Likuiditas, Profitabilitas pada PT Eterindo Wahanatama Tbk dan PT Waskita Karya Tbk.

Dalam penelitian ini metode asosiatif digunakan untuk mengetahui pengaruh Rasio Likuiditas terhadap Financial Distress, pengaruh profitabilitas terhadap Financial Distress. Teknik analisis yang digunakan adalah teknik analisis linear sederhana, analisis linear berganda, dan untuk pengujian hipotesis adalah uji statistik secara parsial (uji t) dan uji secara simultan (uji f)
HASIL DAN PEMBAHASAN

Tabel 1 Koefisien Korelasi antara Likuiditas dan Profitabilitas dalam mengukur Financial Distress

\begin{tabular}{|c|c|c|c|c|}
\hline \multirow{2}{*}{\multicolumn{2}{|c|}{ ModelR }} & \multirow{2}{*}{$\begin{array}{l}\text { R } \\
\text { Square }\end{array}$} & \multicolumn{2}{|c|}{$\begin{array}{l}\text { Std. Error } \\
\text { Adiusted } R \text { of the }\end{array}$} \\
\hline & & & Square & Estimate \\
\hline 1 & $412^{\mathrm{a}}$ & 170 &, 113 & 5,94663 \\
\hline
\end{tabular}

Berdasarkan perhitungan di atas, dapat diketahui bahwa korelasi variabel Likuiditas dan profitabilitas adalah sebesar 0,412 (lihat nilai R pada tabel di atas).

\section{Koefesien Determinasi}

Penghitungan koefisien determinasi ini dilakukan untuk mengetahui Likuiditas dan profitabilitas dalam mengukur financial distress pada PT.Eterindo Wahanatama Tbk dan PT. Waskita Karya Tbk. yang terdaftar di BEI. Menurut Sugiyono (2012:258) dapat dihitung dengan menggunakan rumus koefisien determinasi sebagai berikut:

$$
\mathrm{Kd}=\mathrm{r}^{2} \times 100 \%
$$

Dimana:

$\mathrm{Kd}=$ Koefisien Determinasi

$\mathrm{r} \quad=$ Koefisien korelasi

Perhitungannya adalah sebagai berikut:

$$
\begin{aligned}
\mathrm{Kd} & =\mathrm{r}^{2} \times 100 \% \\
& =(0,412)^{2} \times 100 \% \\
& =0,284 \times 100 \% \\
& =28,4 \%
\end{aligned}
$$

Berdasarkanperhitungan koefisien determinasi yang telah peneliti lakukan, diketahui bahwa nilai $\mathrm{Kd}=28,4 \%$ sedangkan sisanya $71,6 \% \quad(100 \%$ $28,4 \%=85,4 \%$ ) dari faktor yang tidak diteliti. Maka dapat disimpulkan bahwa Likuiditas (CR) dan profitabilitas 
(ROA) terhadap financial distress $\mathrm{Kd}$ mendekati 0 maka pengaruh Likuiditas (CR) dan Profitabilitas (ROA) dalam mengukur financial distress hubungannya lemah.

\section{Regresi Linear Berganda}

\section{Tabel 2 Hasil Perhitungan Regresi Linear Berganda}

\begin{tabular}{|c|c|c|c|c|c|}
\hline \multirow[b]{2}{*}{ Model } & \multicolumn{2}{|c|}{$\begin{array}{c}\text { Unstandardized } \\
\text { Coefficients } \\
\end{array}$} & $\begin{array}{l}\text { Standard } \\
\text { ized } \\
\text { Coefficie } \\
\text { nts } \\
\end{array}$ & \multirow[b]{2}{*}{$\mathbf{t}$} & \multirow[b]{2}{*}{ Sig. } \\
\hline & B & $\begin{array}{l}\text { Std. } \\
\text { Error }\end{array}$ & Beta & & \\
\hline $\begin{array}{ll}1 & \begin{array}{l}\text { (Cons } \\
\text { tant })\end{array}\end{array}$ & $-2,320$ & 1,827 & & $-1,270$ &, 214 \\
\hline CR & , 155 & ,245 & , 107 & 632 & ,532 \\
\hline ROA & 667 & ,283 & ,400 & 2,361 & ,025 \\
\hline
\end{tabular}

Dari hasil output SPSS 24 di atas, dapat diketahui persamaan regresi ganda yaitu:

$$
\begin{array}{ll}
\mathrm{a} & =-2,320 \\
\mathrm{~b}_{1} & =0,155 \\
\mathrm{~b}_{2} & =0,667
\end{array}
$$

Selanjutnya didapat persamaan regresi linier berganda untuk dua predikator (likuiditas dan profitabilitas) adalah: $\mathrm{Y}^{*}=-2,320+0,155 \mathrm{X}_{1}+0,667$ $\mathrm{X}_{2}$. Berdasarkan persamaan di atas, diketahui terdapat pengaruh positif antara likuiditas (CR) (variabel X1) dan profitabilitas (variabel X2) terhadap financial distress (variabel Y).

1. Angka konstanta sebesar $-2,320$ menyatakan bahwa tidak ada Likuiditas (CR) dan Profitabilitas (ROA) maka financial distress akan sebesar -2,320.

2. Koefesien regresi Likuiditas 0,155 (X1) menyatakan bahwa setiap penambahan 1 kali Likuiditas (CR) maka akan mengalami kenaikan sebesar 0,155.

3. Koefesien regresi profitabilitas (ROA) 0,667 (X2) menyatakan bahwa setiap penambahan 1 kali profitabilitas maka akan mengalami kenaikan financial distress sebesar 0,7 . Dibulatkan dari $(0,667)$.

\section{Hasil Uji T dan Uji F Likuiditas (Current Ratio)}

Dari Hasil pengujian dapat dilihat bahwa variabel Likuiditas (CR) memiliki $\mathrm{t}$ hitung sebesar 0,632 sementara tingkat signifikan lebih besar dari pada tingkat signifikansi yang telah ditetapkan yaitu $0.532>0.05$. Untuk taraf kesalahan sebesar 5\% t tabel dk = $\mathrm{n}-2=30$ maka di peroleh $\mathrm{t}$ tabel sebesar 2,042 . Maka hasil pengujian hipotesis $t$ hitung $0,632<2.048$. Hal ini menunjukan bahwa Likuiditas memiliki pengaruh positif terhadap financial distress dan tidak signifikan pada perusahaan, sehingga dapat disimpulkan bahwa $\mathrm{H} 1$ ditolak berarti tidak ada pengaruh Likuiditas terhadap financial distress

\section{Profitabilitas}

Berdasarkan hasil pengujian dapat dilihat bahwa variabel profitabilitas $\mathrm{t}$ hitung sebesar 2,361. sementara tingkat signifikan lebih kecil dari pada tingkat signifikasi yang telah di tetapkan yaitu $0.025<0.05$. Untuk taraf kesalahan sebesar 5\% t tabel dk = n-2=30 maka di peroleh $\mathrm{t}$ tabel sebesar 2,048. Maka hasil pengujian hipotesis t hitung 2,361 $>$ 2.048. Hal ini menunjukan bahwa profitabilitas (ROA) memiliki pengaruh positif terhadap Financial Distress dan signifikan.

\section{Tabel 3 Hasil Uji F}

\begin{tabular}{|l|l|r|r|r|r|r|}
\hline \multicolumn{2}{|l|}{ Model } & $\begin{array}{c}\text { Sum of } \\
\text { Squares }\end{array}$ & \multicolumn{1}{c|}{ df } & $\begin{array}{c}\text { Mean } \\
\text { Square }\end{array}$ & F & Sig. \\
\hline \multirow{4}{*}{1} & Regression & 209,868 & 2 & 104,934 & 2,967 &, $067^{\mathrm{b}}$ \\
\cline { 2 - 7 } & Residual & 1025,509 & 29 & 35,362 & & \\
\cline { 2 - 7 } & Total & 1235,377 & 31 & & & \\
\hline
\end{tabular}




\section{Hasil Uji F}

Berdasarkan tabel diatas dilihat pengaruh simultan variabel bebas terhadap variabel independen likuiditas (CR) dan profitabilitas (ROA) terhadap variabel dependen financial distress. Berdasarkan hasil uji simultan diperoleh F hitung sebesar 2.967 dengan tingkat signifikansi sebesar 0.067. berdasarkan nilai signifikansi yang lebih besar dari 0.05 maka, dapat dikatakan bahwa Likuiditas (CR) dan Profitabilitas (ROA) secara bersama-sama tidak berpengaruh terhadap financial distress.

Berdasarkan $\mathrm{F}$ tabel dengan $\mathrm{dk}$ pembilang $=2$ dan Dk Penyebut $=32-2$ $1=29$ dengan taraf kesalahan yang ditetapkan sebesar $5 \%$ maka diperoleh $\mathrm{F}$ tabel $=2.55$, maka hasil pengujian hipotesis adalah $\mathrm{F}$ hitung $>\mathrm{F}$ tabel 2,967 > 2,55 maka signifikan.

\section{Likuiditas (CR) dalam memprediksi financial distress}

Hasil analisis statistik untuk variabel likuiditas (CR) diketahui bahwa koefesien regresi bernilai positif. Hasil uji $\mathrm{t}$ untuk likuiditas diperoleh sebesar 0.632 dengan tingkat signifikansi lebih besar dibandingkan dengan taraf signifikansi yang ditentukan yaitu $0.532>0.05$ hal ini menunjukan bahwa likuiditas (CR) memiliki pengaruh terhadap financial distress tetapi tidak signifikan. Dengan kata lain H1 dalam penelitian ini ditolak.

\section{Profitabilitas (ROA) dalam memprediksi financial distress}

Hasil analisis statistik untuk variabel Profitabilitas diketahui bahwa koefesien regresi bernilai positif. Hasil uji t untuk profitabilitas diperoleh nilai sebesar 2.361 tingkat signifikan lebih kecil dari taraf signifikan yang telah ditetapkan yaitu $0.025<0.05$. hal ini menunjukan bahwa profitabilitas (ROA) memiliki pengaruh positif dan signifikan dalam memprediksi financial distress.

Likuiditas (CR) dan Profitabilitas (ROA) dalam financial distress Berdasarkan hasil uji F (Simultan) variabel independen Likuiditas (CR) dan Profitabilitas (ROA) terhadap variabel dependen financial distress. Berdasarkan hasil uji simultan diperoleh F hitung sebesar 2.967 dengan taraf signifikansi sebesar 0.069. Berdasarkan nilai signifikansi yang lebih besar dari 0.05 maka, dapat dikatakan bahwa likuiditas (CR) dan profitabilitas (ROA) secara bersama-sama tidak signifikan terdadap financial distres. Tetapi pada $\mathrm{t}$ tabel nilai t hitung lebih besar sebesar $2,967>2.55$ maka t hitung dinyatakan signifikan.

Berdasarkan hasil uji koefesien Determinasi dapat dilihat nilai Adjusted $R^{2}$ sebesar 0.412 dapat diartikan bahwa likuiditas (CR) dan profitabilitas (ROA) dalam financial distress adalah sebesar $28,4 \%$ sisanya $71,6 \%$ dipengaruhi oleh faktor lainnya yang tidak dijelaskan dalam penelitian ini.

\section{PENUTUP}

\section{Kesimpulan}

1. Secara parsial, Likuiditas berpengaruh tetapi tidak signifikan dalam mengukur financial distress Pada PT. Eterindo Wahanatama Tbk dan PT. Waskita karya Tbk.

2. Secara parsial, Profitabilitas berpengaruh dan signifikan dalam mengukur financial distress Pada PT. Eterindo Wahanatama Tbk dan PT. Waskita karya Tbk.

3. Berdasarkan uji F, variabel Likuiditas dan Profitabilitas tidak berpengaruh signifikan secara bersama-sama (simultan) terhadap Financial Distress pada PT. Eterindo Wahanatama Tbk dan PT. Waskita Karya Tbk. 


\section{Saran}

Bagi perusahaan agar lebih memperhatikan kinerja keuangan yang dimiliki karena Financial distress merupakan suatu masalah keuangan yang dihadapi oleh sebuah perusahaan yang ditandai dengan adanya ketidakpastian laba bersih pada masa yang akan datang dan kondisi financial distress terjadi sebelum perusahaan benar-benar mengalami kebangkrutan.

\section{DAFTAR PUSTAKA}

Fahmi, I. (2017). Analisis Laporan Keuangan . Bandung : Alfabeta . Kasmir. (2015). Analisis Laporan Keuangan . Jakarta : PT. Raja Grafindo Persada .
Munawir. (2015). Analisis Laporan keuangan. Jakarta : Salemba Empat.

Puspitawati, L. (2017). Pengaruh Profitabilitas dan Likuiditas terhadap financial distress. Ekonomi .

Sugiyono. (2012). Metode Penelitian Kuantitatif, Kualitatif. Bandung : Alfabeta .

Sugiyono. (2014). Statistik untuk Penelitian. Bandung : Alfabeta . 